\title{
Temporal variability in phosphorus transfers: classifying concentration-discharge event dynamics
}

\author{
Phil Haygarth ${ }^{1}$, Benjamin L. Turner ${ }^{1,5}$, Andy Fraser ${ }^{2}$, Steve Jarvis ${ }^{1}$, Tim Harrod ${ }^{2}$, David Nash ${ }^{3}$, \\ David Halliwell ${ }^{3}$, Trevor Page ${ }^{4}$ and Keith Beven ${ }^{4}$
}

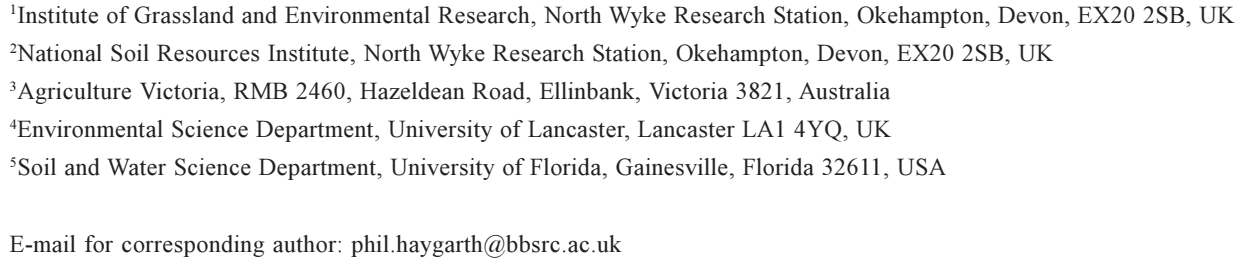

\begin{abstract}
The importance of temporal variability in relationships between phosphorus $(\mathrm{P})$ concentration $\left(\mathrm{C}_{\mathrm{p}}\right)$ and discharge $(\mathrm{Q})$ is linked to a simple means of classifying the circumstances of $\mathrm{C}_{\mathrm{p}}-\mathrm{Q}$ relationships in terms of functional types of response. New experimental data at the upstream interface of grassland soil and catchment systems at a range of scales (lysimeters to headwaters) in England and Australia are used to demonstrate the potential of such an approach. Three types of event are defined as Types 1-3, depending on whether the relative change in $Q$ exceeds the relative change in $C_{p}$ (Type 1), whether $C_{p}$ and $Q$ are positively inter-related (Type 2) and whether $C_{p}$ varies yet $Q$ is unchanged (Type 3). The classification helps to characterise circumstances that can be explained mechanistically in relation to (i) the scale of the study (with a tendency towards Type 1 in small scale lysimeters), (ii) the form of P with a tendency for Type 1 for soluble (i.e., $<0.45 \mu \mathrm{m} P$ forms) and (iii) the sources of $\mathrm{P}$ with Type 3 dominant where $\mathrm{P}$ availability overrides transport controls. This simple framework provides a basis for development of a more complex and quantitative classification of $\mathrm{C}_{\mathrm{p}}-\mathrm{Q}$ relationships that can be developed further to contribute to future models of $\mathrm{P}$ transfer and delivery from slope to stream. Studies that evaluate the temporal dynamics of the transfer of P are currently grossly under-represented in comparison with models based on static/spatial factors.
\end{abstract}

Keywords: phosphorus, concentration, discharge, lysimeters, temporal dynamics, overland flow

\section{Introduction}

The models currently dominant for understanding phosphorus (P) transfer from agricultural soils to streams (Haygarth and Jarvis, 1999; Heathwaite et al., 2003; Lemunyon and Gilbert, 1993) are focused on static/spatial factors, such as farm system (Haygarth et al., 1998b), land use type (Johnes and Butterfield, 2002) and soil P status (Heckrath et al., 1995). In this paper, the importance of temporal variability is explored and it is shown that such 'day to day' changes in P concentration $\left(\mathrm{C}_{\mathrm{p}}\right)$ - discharge (Q) relationships can be at least as important as static/spatial factors.

Nutrient concentration-Q relationships are well established, particularly within the engineering/hydrology disciplines using methods such as hydrograph separation and mixing models (e.g. Leaney et al., 1993; McDonnell et al., 1991). However, among the $\mathrm{P}$ transfer cognoscenti and in the emergent literature, there are relatively few such $\mathrm{C}_{\mathrm{p}}-$ $\mathrm{Q}$ studies that involve $\mathrm{P}$ specifically even though $\mathrm{P}$ dynamics are critical to farming practices (see Table 1 and below for a review of key work). This note examines the importance of these temporal concepts in relation to $\mathrm{P}$ transfer and presents a simple empirical attempt to characterise $\mathrm{C}_{\mathrm{p}}-\mathrm{Q}$ relationships. The paper involves:

1. examination of the theoretical background as to why $\mathrm{C}_{\mathrm{p}}-\mathrm{Q}$ relationship types differ;

2. a proposed classification for $\mathrm{C}_{\mathrm{p}}-\mathrm{Q}$ relationship types;

3. a description of the methods behind the new data;

4. a discussion of how understanding $\mathrm{C}_{\mathrm{p}}-\mathrm{Q}$ relationships 
Temporal variability in phosphorus transfers: classifying concentration-discharge event dynamics

Table 1. A selective review giving examples of phosphorus concentration-discharge circumstances published by previous researchers

\begin{tabular}{|c|c|c|c|}
\hline Source Circumstances & Discharge Circumstances & Concentration-discharge relationship & Reference \\
\hline $\begin{array}{l}\text { Springtime manure additions - } \\
200 \text { tonnes ha }{ }^{-1} \text { (New York, USA) }\end{array}$ & $\begin{array}{l}1319 \mathrm{~mm} \text { annual rainfall, } \\
\text { 'high spring discharge'. } \\
\text { Integration of spring and summer } \\
\text { discharge peak events }\end{array}$ & $\begin{array}{l}\text { High concentration of RP and } \mathrm{UP}<0.45 \mu \mathrm{m} \text {. } \\
\text { Some rise with discharge. }\end{array}$ & $\begin{array}{l}\text { Hergert et al., } 1981 . \\
\text { J. Environ. Qual., } 10 \text {, } \\
\text { 345-349. }\end{array}$ \\
\hline
\end{tabular}

Springtime manure additions -

35 tonnes ha $^{-1}$ (New York, USA)

Springtime manure additions 200 tonnes ha ${ }^{-1}$ (New York, USA)

Springtime manure additions 35 tonnes ha-1 (New York, USA)

Springtime manure additions 200 tonnes ha-1 ${ }^{-1}$ New York, USA)

Grazed grassland 1 ha plots, after fertiliser additions, England

Grazed grassland 1 ha plots, after fertiliser additions, England

Permanent grassland, Lake Sempach, Switzerland

Permanent grassland, Lake Sempach, Switzerland

Permanent grassland, Lake Sempach, Switzerland, after manure additions

Cut grassland, $30 \mathrm{~m}^{2}$ plots

Cut grassland $30 \mathrm{~m}^{2}$ plots, $\mathrm{P}$ fertiliser added equivalent to $29 \mathrm{~kg}$ TP ha-

Cut grassland $30 \mathrm{~m}^{2}$ plots, cattle slurry added equivalent to 29 kg TP ha ${ }^{-1}$
$1319 \mathrm{~mm}$ annual rainfall, 'high spring discharge'. Integration of spring and summer discharge peak events

$1319 \mathrm{~mm}$ annual rainfall, 'high spring discharge'. Integration of spring and summer discharge peak events

$1319 \mathrm{~mm}$ annual rainfall, 'high spring discharge'. Integration of spring and summer discharge peak events

Irrigation experiment in the Autumn with $640 \mathrm{ml}+430 \mathrm{ml}+530 \mathrm{ml}$ applied in successive days

$1100 \mathrm{~mm}$ annual rainfall, $50 \mathrm{~mm}$ rainfall over four days May 1994 six days after addition of $16 \mathrm{~kg}$ triplesuperphosphate fertilizer, single discharge peak event

$1100 \mathrm{~mm}$ annual rainfall,

140 samples of discharge and concentration (from integration of 10 occasions $\times 14$ plots) during spring and autumn discharges from 1 ha plots during 1994.

Excluded 'high' discharge events.

$1200 \mathrm{~mm}$ annual rainfall, only selecting individual single discharge peak events

$1200 \mathrm{~mm}$ annual rainfall, all events (data plotted in log scale)

$1200 \mathrm{~mm}$ annual rainfall, individual single discharge peak event concentrations 1-2 days after application

Annual rainfall $1100 \mathrm{~mm}$, this event $49 \mathrm{~mm}$ rainfall in 169 hours, intensity $0.2-3 \mathrm{~mm} \mathrm{~h}^{-1}$

Annual rainfall $1100 \mathrm{~mm}$, this event $49 \mathrm{~mm}$ rainfall in 169 hours, intensity $0.2-3 \mathrm{~mm} \mathrm{~h}^{-1}$

Annual rainfall $1100 \mathrm{~mm}$, this event $49 \mathrm{~mm}$ rainfall in 169 hours, intensity $0.2-3 \mathrm{~mm} \mathrm{~h}^{-1}$ but not on a longer term time scale

High concentration of RP and UP $<0.45 \mu \mathrm{m}$. Not clearly related to discharge.

'Reduced' concentration of RP and UP $<0.45 \mu \mathrm{m}$ and UP in the autumn after a spring addition. No relationship between discharge and concentration.

'Reduced' concentration of RP and UP $<0.45 \mu \mathrm{m}$ and UP in the autumn after a spring addition. No relationship between discharge and concentration.

$\mathrm{RP}<0.45 \mu \mathrm{m}(90 \%$ of the $\mathrm{TP}<0.45 \mu \mathrm{m})$ dramatically rose in relation to increases in discharge.

Total $\mathrm{P}$ responded to the discharge hydrograph, $\mathrm{RP}<0.45 \mu \mathrm{m}$ was unaffected.

Relationship between $\mathrm{RP}<0.45 \mu \mathrm{m}$ and discharge was not significant.

Relationship between TP and discharge was significant but only explained $14 \%$ of the variation.

Positive correlation between concentration of $\mathrm{RP}<0.45 \mu \mathrm{m}$ and discharge for $27 / 30$ peaks and $64-79 \%$ of variance between concentration and discharge explained in linear regressions.

$20-34 \%$ of variance between concentration and discharge explained in linear regressions.

Pronounced storm discharge hydrograph but TP concentration remained relatively unchanged throughout.

Pronounced storm discharge hydrograph with corresponding rise in TP concentration.

Pronounced storm discharge hydrograph with corresponding rise in TP concentration.
Hergert et al., 1981.

J. Environ. Qual., 10, 345-349.

Hergert et al., 1981.

J. Environ. Qual., 10, 345-349.

Hergert et al., 1981.

J. Environ. Qual., 10, 345-349.

Hergert et al., 1981. J. Environ. Qual., 10, 345-349.

Haygarth and Jarvis, 1997. Wat Res., 31, 140-148.

Haygarth and Jarvis, 1997. Water Res., 31, 140-148.

Stamm et al., 1998,

J. Environ. Qual., 27, 515-522.

Stamm et al., 1998 ,

J. Environ. Qual., 27, 515-522.

Stamm et al., 1998,

J. Environ. Qual., 27, 515-522.

Preedy et al., 2001,

J. Environ. Qual., 30,

2105-2112

Preedy et al., 2001,

J. Environ. Qual., 30,

2105-2112

Preedy et al., 2001,

J. Environ. Qual., 30, 2105-2112 
can contribute to new understandings of $\mathrm{P}$ transfer dynamics.

\section{Theoretical background}

Phosphorus concentration and Q relationships have been discussed previously by a limited number of researchers (e.g. Cooke, 1988; Haygarth and Jarvis, 1997; Hergert et al., 1981a; Hergert et al., 1981b; Pionke et al., 1993; Preedy et al., 2001; Sinaj et al., 2002; Stamm et al., 1998). Table 1 presents a summary of these. From the literature, three types of $\mathrm{C}_{\mathrm{p}}-\mathrm{Q}$ response can be identified.

In Type 1, $\mathrm{C}_{\mathrm{p}}$ remains relatively constant in relation to $\mathrm{Q}$. This might arise from a steady-state situation between the dissolution kinetics of a relatively homogenous soil and the velocity of the water flow and where the reservoir of the soil water may not drain too quickly to prevent exchange of $\mathrm{P}$ between soil and solution. The theoretical extreme of this could be homogenised sand.

In Type 2, $\mathrm{C}_{\mathrm{p}}$ and $\mathrm{Q}$ seem to be related, when the presence of fast flow causes an apparent disequilibrium in the $\mathrm{C}_{\mathrm{p}}$ supply. In theory, this may arise when:

1. Flow causes the physical entrainment of particulate and colloidal matter (with $\mathrm{P}$ attached) during rapid water flows (Haygarth and Jarvis, 1997; Haygarth et al., 1997). This is probably the commonest example.

2. The fast flow means that the water takes a pathway different from that 'normally' experienced during saturated base flow, where there is little opportunity for mixing and re-adsorption of P. This may be exacerbated in circumstances where the fast flow path interacts with a 'new' high P source. Indeed, Haygarth et al. (1998a) have shown that where soil $\mathrm{P}$ is concentrated in the top few $\mathrm{cm}$ of soil, it provides a source with a high potential for interacting with any fast overland or near-surface flows. Macropore flow has also been shown to be important in these circumstances (Stamm et al., 1998).

3. The changes in soil moisture affect soil biochemistry and additional $\mathrm{P}$ is supplied. Recent studies have shown that dynamics of soil wetting and drying may release a considerable quantity of $\mathrm{P}$ into soil solution including mobile $\mathrm{P}$ from the soil microbial biomass (Turner and Haygarth, 2001).

4. A decline of $\mathrm{C}_{\mathrm{p}}$ in relation to high $\mathrm{Q}$, reflects dilution and depletion of source.

Type 3 is the opposite of Type 1 , where changes in $C_{p}$ occur even though $\mathrm{Q}$ remains relatively constant. This reflects an enriched supply or source of $\mathrm{P}$ to the system and could occur when fertiliser or manure is added to soil
(Haygarth and Jarvis, 1997; Hergert et al., 1981a; Hergert et al., 1981b; Pionke et al., 1993; Preedy et al., 2001; Stamm et al., 1998).

\section{Proposed classification for $C_{p}-Q$ relationship types}

Based upon the theoretical background, the $\mathrm{C}_{\mathrm{p}}-\mathrm{Q}$ relationships can be classified in terms of a simple decision tree (Fig. 1).

1. Define the duration (i.e. start and endpoint) of the time series to be classified, e.g. a storm, three storms, rising limb, falling limb etc..

2. Determine whether there is a significant change in $C_{p}$ or $\mathrm{Q}$ during the time series i.e. is there an 'event' to be classified?

3. Is the event characterised by a change in $\mathrm{C}_{\mathrm{p}}$ and/or $\mathrm{Q}$ ?

- Type 1 events occur when the relative change in $\mathrm{Q}$ is $>$ than the relative change in $\mathrm{C}_{\mathrm{p}}$.

- If both $\mathrm{C}_{\mathrm{p}}$ and $\mathrm{Q}$ change then the event is Type 2 .

- If $\mathrm{C}_{\mathrm{p}}$ only changes then the event is Type 3 .

\section{Data collected to test the classification for $C_{p}-Q$ relationship types}

The classification was tested on new data, derived from analysis of hydrographs and time series data for P export from a range of hydrologically isolated 'lysimeters' and headwater catchments from different soils of varying $\mathrm{P}$ content, for a variety of rainfall-runoff conditions in England and Australia. All samples were collected, prepared and analysed for either reactive $P$ that was filtered $(<0.45 \mu \mathrm{m}$, $\mathrm{RP}_{<0.45 \mu \mathrm{m}}$ ) (Haygarth et al., 1995; Haygarth and Sharpley, 2000) or total $P$ that was unfiltered (TP), using standard protocols (Eisenreich et al., 1975; Murphy and Riley, 1962; Rowland and Haygarth, 1997). A full description of all the sites used follows below (Table 2 summarises soil type, $P$ status, P management and hydro-sampling methods):

Monolith lysimeters. Cylindrical monolith lysimeters, 135 $\mathrm{cm}$ deep and $80 \mathrm{~cm}$ diameter, sampled intact to preserve the soil structure (Belford, 1979) were installed in a field site (UK national mapping grid reference NGR SX 657 983) at North Wyke Research Station, Devon, UK, in 1992. The lysimeters supported swards that were dominated by perennial ryegrass (Lolium perenne L.) and received inorganic fertiliser nitrogen $(\mathrm{N}), \mathrm{P}$ and potassium $(\mathrm{K})$, in accordance with recommended practice for cut grassland 


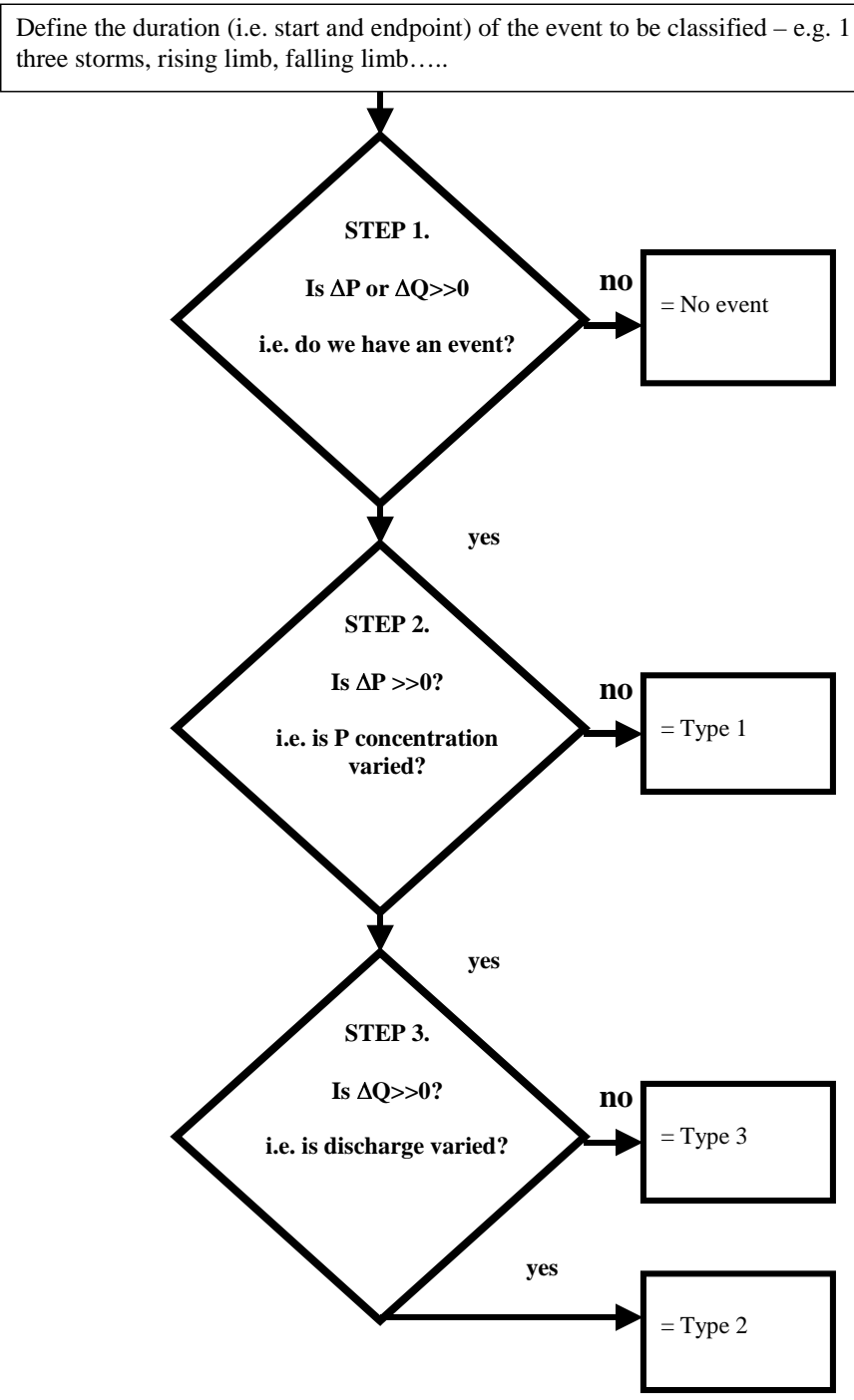

Fig. 1. Proposed system for a functional type classification of phosphorus concentration-discharge relationships

in England and Wales (MAFF, 1994). The lysimeters were exposed to natural rainfall and environmental conditions and water draining under gravity was collected in $25 \mathrm{~L}$ vessels in an underground chamber (Turner and Haygarth, 2000). There were three soil types and four replicate lysimeters of each, being; (1) a clay loam (USDA Dystrochrepts), (2) a sandy-loam (USDA Hapludalfs) and (3) a sand (USDA Udipsamments). The temporal trend, based on seven-day cumulative Q over a winter field capacity season, from $2^{\text {nd }}$ December 1997 until $19^{\text {th }}$ May 1998, was studied. The Dystrochrepts soil was also analysed more frequently, using samples gathered daily, during the period $18^{\text {th }}$ February-4 $4^{\text {th }}$ March 1997.

1.8 hectare size overland/interflow plots. This experiment used a 1.8 hectare paddock as part of a 120 ha farm on which approximately 350 dairy cows graze all year round at Darnum, in West Gippsland, Victoria, Australia (38 10' S, $\left.14603^{\prime} \mathrm{E}\right)$. The soil was a fine sandy loam A horizon overlaying a light to medium clay at approximately $75 \mathrm{~cm}$ (USDA Haplustults). The pasture was predominantly perennial ryegrass and white clover (Trifolium repens L.) and received $60,80,110$ and $110 \mathrm{~kg} \mathrm{P} \mathrm{ha}^{-1}$ annually from 1993 to 1996. The experimental area drains to a natural depression where a culvert conveys the water away. Overland flow plus interflow to $7.5 \mathrm{~cm}$ were sampled by a diversion wall, buried $7.5 \mathrm{~cm}$ into the soil. Water sampling was discharge-integrated to maximise sampling frequency at higher Q for 34 events $>0.027$ mm (runoff) between 1994 and 1996.

Den Brook headwater catchment. This 48 ha catchment was 
Table 2. Description of the soils and hydrological circumstances examined in this study

\begin{tabular}{|c|c|c|c|c|c|}
\hline $\begin{array}{l}\text { Soil type } \\
\text { (USDA system) }\end{array}$ & Location & $\begin{array}{l}\text { Hydrological circumstances } \\
\text { and sampling }\end{array}$ & Management & $\begin{array}{l}\text { Annual } \\
\text { rainfall } \\
\text { (mm) }\end{array}$ & $\begin{array}{l}\text { Soil Olsen P } \\
\quad\left(m g \mathrm{~kg}^{-1}\right)\end{array}$ \\
\hline Dystrochrepts & $\begin{array}{l}\text { Institute of Grassland and } \\
\text { Environmental Research, } \\
\text { North Wyke, Devon, UK }\end{array}$ & $\begin{array}{l}80 \mathrm{~cm} \text { diameter } \times 135 \mathrm{~cm} \text {, } \\
\text { deep monolith lysimeter: } \\
\text { percolate at } 135 \mathrm{~cm}\end{array}$ & $\begin{array}{l}\text { Cut grassland, (Lolium perenne } \mathrm{L} . \text { ), } \\
25 \mathrm{~kg} \mathrm{P} \mathrm{ha}^{-1} \text { per year as fertilizer, } \\
4 \text { replicates }\end{array}$ & 1100 & 24 \\
\hline Hapludalfs & $\begin{array}{l}\text { Institute of Grassland and } \\
\text { Environmental Research, } \\
\text { North Wyke, Devon, UK }\end{array}$ & $\begin{array}{l}80 \mathrm{~cm} \text { diameter } \times 135 \mathrm{~cm} \text {, } \\
\text { deep monolith lysimeter: } \\
\text { percolate at } 135 \mathrm{~cm}\end{array}$ & $\begin{array}{l}\text { Cut grassland, (Lolium perenne L.), } \\
25 \mathrm{~kg} \mathrm{P} \mathrm{ha}^{-1} \text { per year as fertilizer, } \\
4 \text { replicates }\end{array}$ & 1100 & 46 \\
\hline Udipsamments & $\begin{array}{l}\text { Institute of Grassland and } \\
\text { Environmental Research, } \\
\text { North Wyke, Devon, UK }\end{array}$ & $\begin{array}{l}80 \mathrm{~cm} \text { diameter } \times 135 \mathrm{~cm} \text {, } \\
\text { deep monolith lysimeter: } \\
\text { percolate at } 135 \mathrm{~cm}\end{array}$ & $\begin{array}{l}\text { Cut grassland, (Lolium perenne } \mathrm{L} . \text { ), } \\
25 \mathrm{~kg} \mathrm{P} \mathrm{ha}^{-1} \text { per year as fertilizer, } \\
4 \text { replicates }\end{array}$ & 1100 & 75 \\
\hline Haplustults & $\begin{array}{l}\text { Darnum, Victoria, } \\
\text { Australia }\end{array}$ & $\begin{array}{l}1.8 \text { ha paddock, overland } \\
\text { flow plus interflow } \\
\text { to } 7.5 \mathrm{~cm}\end{array}$ & $\begin{array}{l}\text { Grazed pasture, Lolium perenne L. } \\
\text { and Trifolium repens L., 60, 80, } \\
110 \text { and } 110 \mathrm{~kg} \mathrm{P} \mathrm{ha}^{-1} \text { annually } \\
\text { from } 1993 \text { to } 1996\end{array}$ & 1000 & 40 \\
\hline Dystrochrepts & Drewston, Devon, UK & $\begin{array}{l}22 \text { ha first order headwater } \\
\text { catchment, } 639 \mathrm{~mm} \text { runoff }\end{array}$ & $\begin{array}{l}\text { Grazed pasture, Lolium perenne } \\
\text { mixture of beef cattle and sheep }\end{array}$ & 1311 & 49 \\
\hline Typic haplaquepts & Den Brook, Devon, UK & $\begin{array}{l}48 \text { ha first order headwater } \\
\text { catchmentl, } 610 \mathrm{~mm} \text { runoff }\end{array}$ & $\begin{array}{l}\text { Grazed pasture, Lolium perenne } \\
\text { mixture of cows, beef cattle and sheep }\end{array}$ & 1011 & 54 \\
\hline
\end{tabular}

characterised by a slowly permeable seasonally waterlogged clay soil (USDA Typic Haplaquept) and had an extensive network of agricultural tile drains under the surface. The catchment was managed predominately as mixed grassland with some beef cattle, sheep and a dairy herd, as well as approximately 1 ha of maize, harvested in the autumn. The median Olsen $\mathrm{P}$ value for the whole catchment was $54 \mathrm{mg}$ $\mathrm{kg}^{-1}(0-7.5 \mathrm{~cm})$. There was also a hard standing area for cattle within the catchment that drained, intermittently, polluted farmyard runoff directly into the stream. The sward was dominated by perennial ryegrass and received inorganic fertiliser $\mathrm{N}, \mathrm{P}$ and $\mathrm{K}$ plus manure and excretal returns consistent with recommended practice (MAFF, 1994). Annual average rainfall for the period Dec 2001-Nov 2002 was $1011 \mathrm{~mm}$ with $610 \mathrm{~mm}$ total runoff determined at the flume at the outlet (located at UK national mapping grid reference NGR SX 677 998). Water samples were autocollected in proportion to the flow and transferred to the laboratory for analysis within 24 hours of sampling.

Drewston headwater catchment. This 22 ha catchment was characterised by a well drained fine loamy soil (USDA Dystrochrept) and was approximately 10 miles from the Den Brook catchment, thereby being subjected to a broadly similar and comparable hydro-climatic condition. The catchment was managed predominately as mixed grassland with some beef cattle and sheep, as well as having woodland surrounding the stream in the lower part of the catchment.
The median Olsen $\mathrm{P}$ value for the whole catchment was $49 \mathrm{mg} \mathrm{kg} \mathrm{kg}^{-1}(0-7.5 \mathrm{~cm})$. The sward was dominated by perennial ryegrass and received inorganic fertiliser $\mathrm{N}, \mathrm{P}$ and $\mathrm{K}$ plus manure and excretal returns consistent with recommended practice (MAFF, 1994). Annual average rainfall in the period Dec 2001-Nov 2002 was $1311 \mathrm{~mm}$ with $639 \mathrm{~mm}$ total runoff determined at the flume outlet (UK national mapping grid reference NGR SX 726 878). Water samples were auto-collected in proportion to the flow and transferred to the laboratory for analysis within 24 hours of sampling.

\section{How understanding $\mathrm{C}_{\mathrm{p}}-\mathrm{Q}$ relationships can contribute to new understandings for phosphorus transfer}

Pionke et al. (1996) have demonstrated previously the importance of 'events' and proposed a system of classifying nutrient export by separating hydrograph Q conditions in relation to 'base flow', 'elevated base flow', 'storm flow' and 'unclassified flow'. This classification system was based on $\mathrm{Q}$ and did not account for differences in $\mathrm{C}_{\mathrm{p}}$. In contrast, the approach taken here is able to describe all types of $\mathrm{C}_{\mathrm{p}}-\mathrm{Q}$ relationships that emerge from the data sets. In Figs. 2-6, examples are presented as illustrations. 


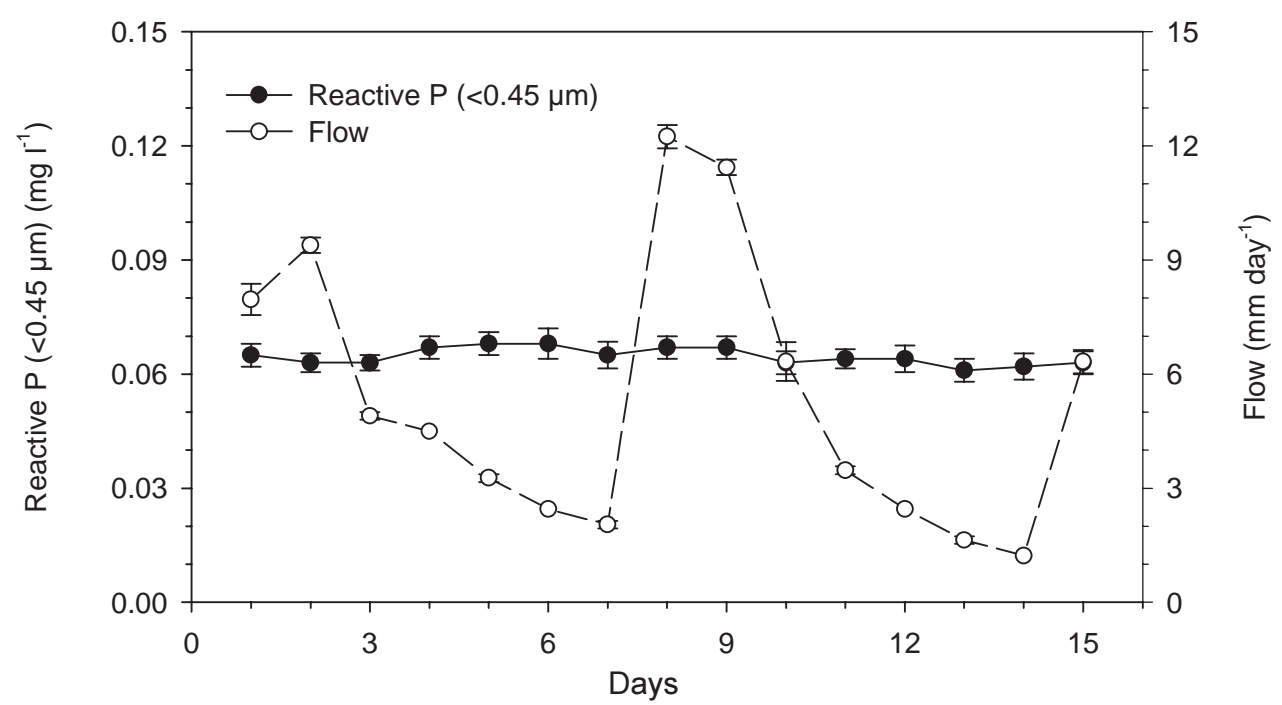

Fig. 2. Type 1 response in monolith lysimeters at daily resolution for two weeks, (one soil type): The temporal trend in $R P_{<0.45}$ mm concentration in leachate and discharge from a Dystrochrepts soil under a cut grassland monolith lysimeters in Devon, UK. Data are from samples gathered daily, during the period $18^{\text {th }}$ February $-4^{\text {th }}$ March 1997, vertical bars represent standard errors of $n=4$ replicate lysimeters).

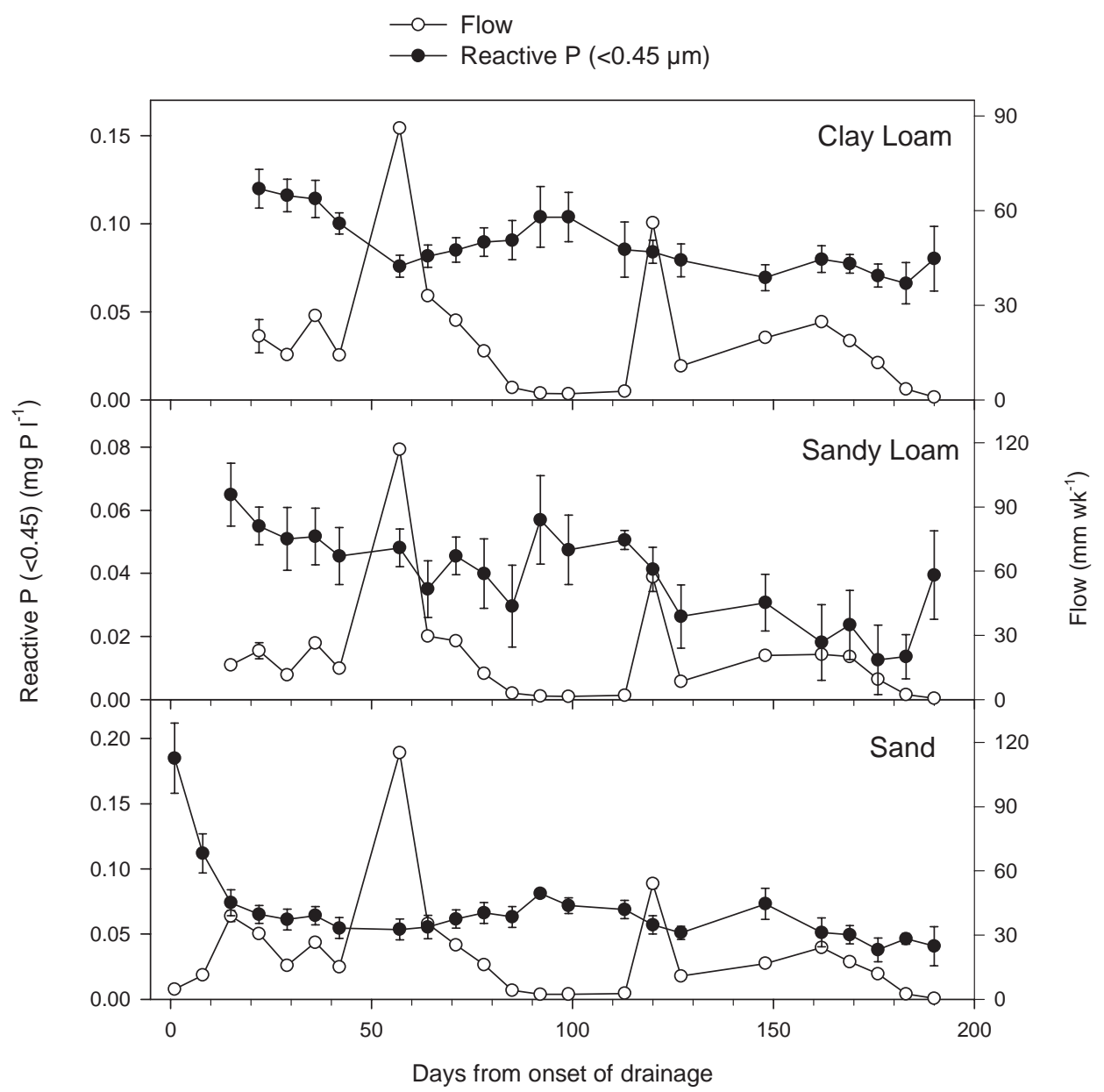

Fig. 3. Type 1 response in monolith lysimeters, at weekly resolution for a drainage season (3 soil types): The temporal trend in RP concentration in leachate and discharge from three contrasting soil types in monolith lysimeters under cut grassland in Devon, UK. The temporal trend is based on a 7-day cumulative discharge over a winter field capacity season, from $2^{\text {nd }}$ December 1997 until 19th May 1998, vertical bars represent standard errors of $n=4$ replicate lysimeters). 
P. Haygarth, B.L.Turner, A. Fraser, S. Jarvis, T. Harrod, D. Nash, D. Halliwell, T. Page and K. Beven

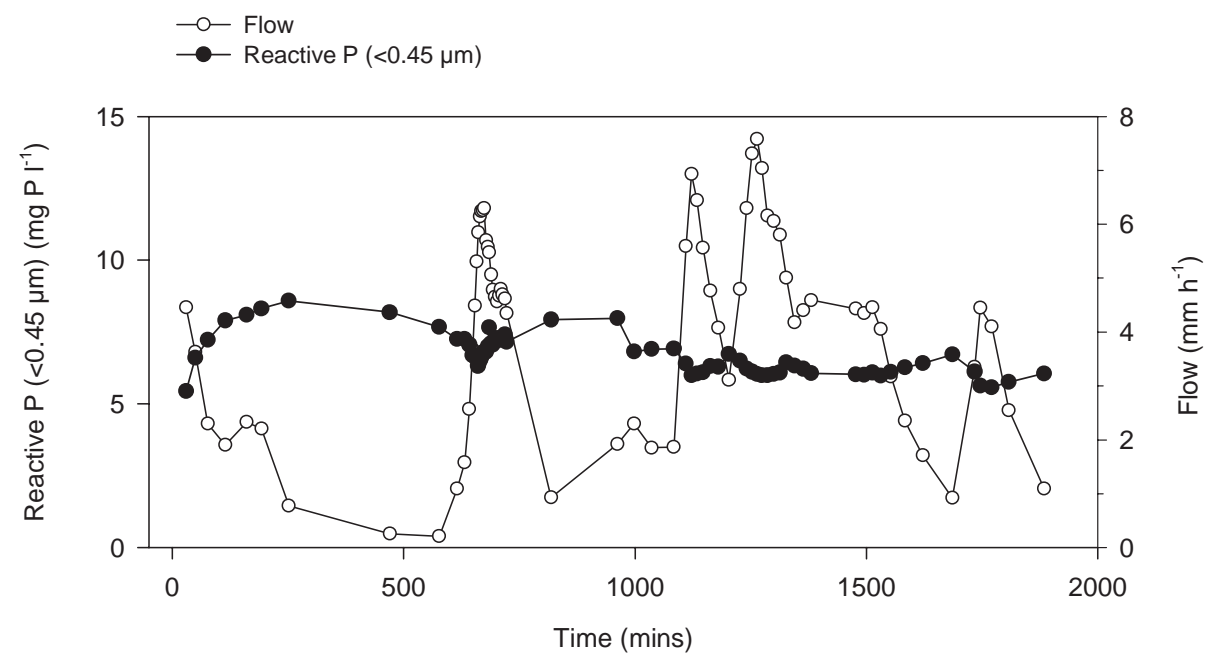

Fig. 4. Type 1 response in overland flow from a small paddock from 1.8 ha overland flow plus interflow plots from Darnum in Victoria, Australia. These data are from the longest continuous event of $>0.027 \mathrm{~mm}$ at this site. This data was collected on a minute by minute scale on 6-7 Nov 1994.
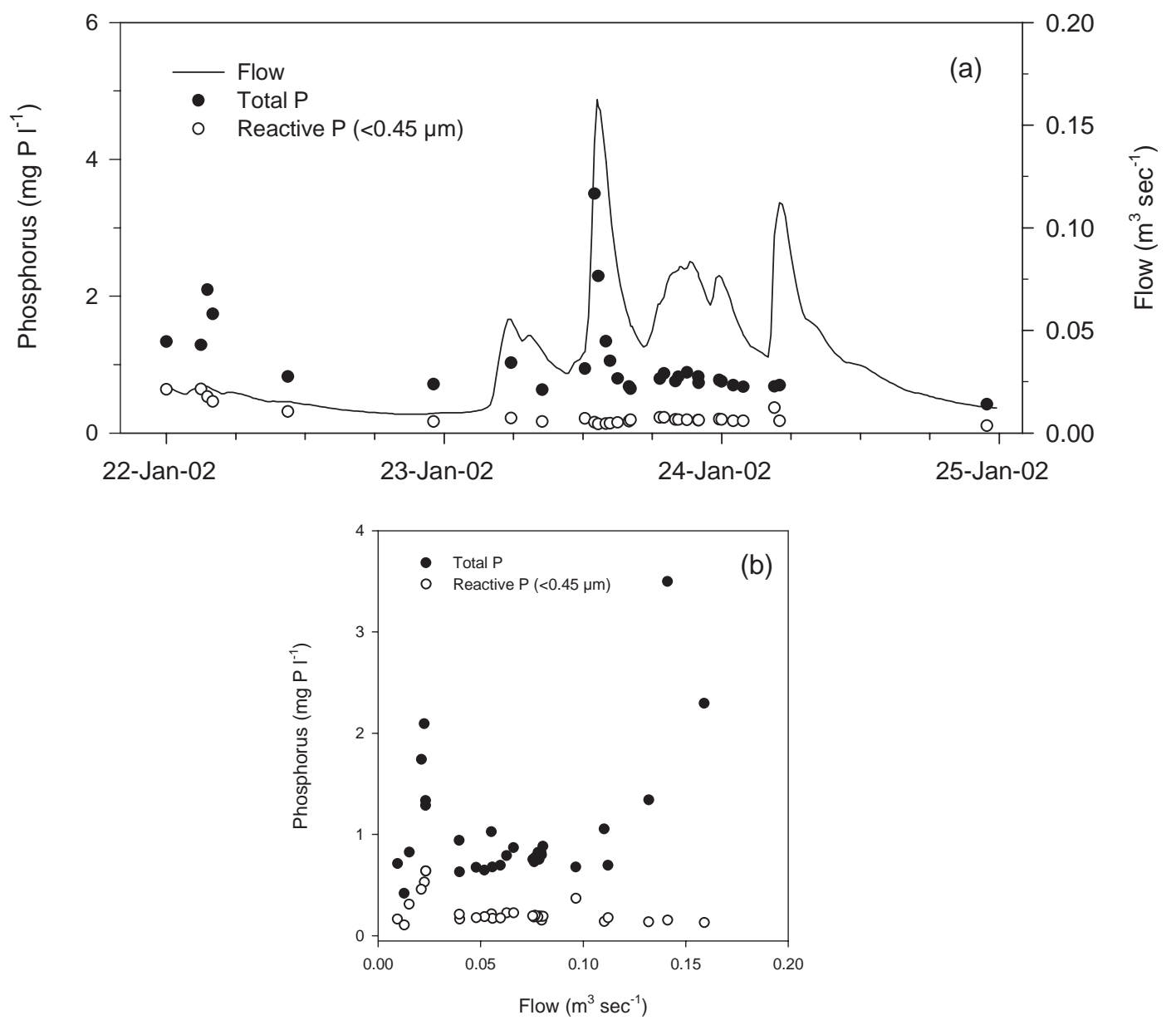

Fig. 5. Different phosphorus forms give different functional type responses: Type 1 and 2 responses in one-headwater catchment for different $P$

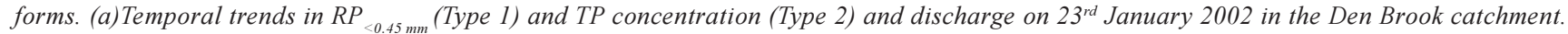
(b) Scatter plot of the resulting relationship between $C_{p}$ and $Q$. 


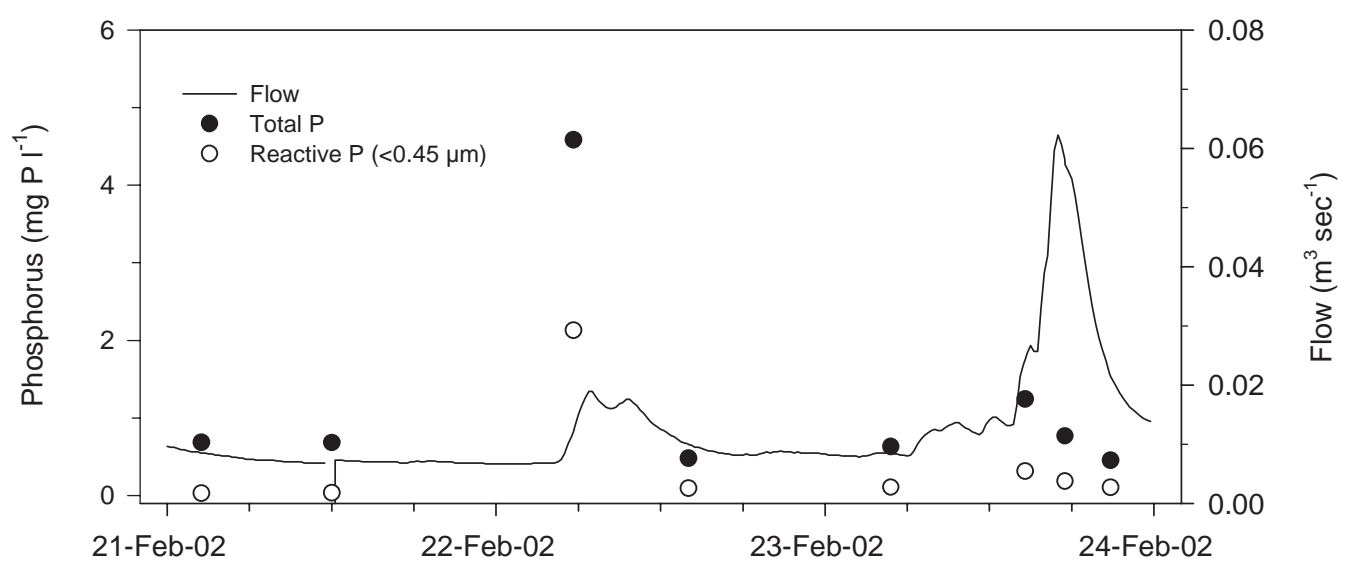

Fig. 6. Type 3 response in one-headwater catchment: Temporal trends in a) $R P_{<0.45 m}$ and b) TP concentration and discharge on $21-24$ February 2002 in the Den Brook catchment, following wash down of animal housing area into the stream.

Example of Type 1 circumstances and the effect of sample frequency. Type 1 transfers (akin to the term 'level 1' that was first used by Haygarth and Jarvis (1999) and Haygarth et al. (2000b)) are similar to 'systematic' transfers described by Nash et al. (2001) and 'underlying agricultural transfers' (Haygarth et al., 2000b), associated with 'base flow' (1996). Type $1 \mathrm{C}_{\mathrm{p}}-\mathrm{Q}$ relationships exemplify a strongly damped 'flat' or 'smooth' $\mathrm{P}$ breakthrough, in relation to a relatively varied response of $\mathrm{Q}$, suggesting that matrix type Qs are dominant, where water, $\mathrm{P}$ and soil have become reasonably well mixed. In these circumstances, Q limits P transfer. Type 1 responses were most common from small scale observations (i.e., monolith lysimeters).

Time series plots of $\mathrm{RP}_{<0.45 \mu \mathrm{m}}$ breakthrough concentrations and Q for the Dystrochrepts monoliths are shown in Fig. 2, using samples gathered daily during the period $18^{\text {th }}$ February-4 $4^{\text {th }}$ March 1997 (Fig. 2 - clay loam) and collected weekly for the entire hydrological drainage period 1997-1998 (Fig. 3 - clay loam, sandy loam and sand). Double Fourier models (Genstat 5 Committee, 1993) were fitted to both $\mathrm{Q}$ and $\mathrm{RP}_{<0.45 \mu \mathrm{m}}$ concentration. For the clay loam, the maximum amplitudes of the Qs were 78.8\% (Fig. 2, daily sample frequency) and $99.5 \%$ (Fig. 3 - weekly sample frequency), whereas for $\mathrm{RP}_{<0.45 \mu \mathrm{m}}$ concentration they were $3.7 \%$ (Fig. 2 - daily) and $45.9 \%$ (Fig. 3 - weekly). In the first example (Fig. 2 - daily), the maximum amplitude of Q was 21 times greater than the maximum amplitude of $\mathrm{RP}_{<0.45 \mu \mathrm{m}}$ and in the second longer sample period (Fig. 3, weekly), it was 2.7 times greater than that of the $\mathrm{RP}_{<0.45 \mu \mathrm{m}}$. Figure 3 also shows weekly sample data from the other two monolith soils (Hapludalfs and Udipsamments) plotted in a similar manner. In these hydrographs, the maximum amplitudes of the Qs were larger than those for $\mathrm{RP}_{<0.45 \mu \mathrm{m}}$ concentrations in the time series. A similar Type 1 classification is shown for the 1.8 ha size overland Q plots from Australia (Haplustults, Fig. 4), although in this example there is additional finer structure to the hysteresis. At the beginning of the time series values are clearly recovering on the falling limb of the first runoff event and the pattern is repeated throughout successive Q peaks. All these data exhibit a Type 1 classification.

Example - Type 1 and 2 circumstances and the effect of phosphorus forms. Different $\mathrm{P}$ forms can also result in different functional type behaviour. Figure 5 is an example from Den Brook from January 2002, where, in the main storm peak, temporal trends in $\mathrm{RP}_{<0.45 \mu \mathrm{m}}$ are Type 1 but total $\mathrm{P}$ forms gave a Type 2 response. This probably reflects different processes of mobilisation of different forms of $\mathrm{P}$. Where $\mathrm{P}$ forms are filtered, they predominantly reflect solubilisation of $\mathrm{P}$ that can be relatively easily mixed in matrix flow paths of the soil. In contrast, TP includes P forms that are not soluble and thus reflects physical detachment of colloids and particles with $\mathrm{P}$ attached, responding to the physical energy of the rainfall (Haygarth and Jarvis, 1997). Interestingly, before and after the main storm peak where $\mathrm{Q}$ is lower, TP actually exhibits a Type 1 response, illustrating the importance of hydrological thresholds in determining the switch in hydrological energy (Haygarth et al., 2000a). Figure $5 \mathrm{~b}$ shows the scatter plot of the relationship between $\mathrm{C}_{\mathrm{p}}$ and $\mathrm{Q}$ is more widely distributed than that for $\mathrm{RP}_{<0.45 \mu \mathrm{m}}$ which, being more akin to Type 1, is less responsive to $\mathrm{Q}$.

Example of Type 3 circumstances and farm management. An example of a Type 3 response from the Den Brook catchment occurred on 21-24 $4^{\text {th }}$ February 2002, following leakage of the slurry storage pit into the drain that feeds the stream (Fig. 6). This type of event is clearly source-dominated. 


\section{Benefits of a temporal approach to studying phosphorus transfer}

This simple rationalisation of $\mathrm{C}_{\mathrm{p}}-\mathrm{Q}$ relationships emphasises the importance of a temporal approach characterising circumstances of $\mathrm{P}$ transfer. With the exception of a few studies cited earlier, the overall trend within the P transfer cognoscenti has been to focus on static/spatial factors. Events are a source of important information for helping the understanding of patterns and processes and clearly $\mathrm{C}_{\mathrm{p}}$ and $\mathrm{Q}$ are the central components of these. Although factors such as soil $P$ status are important in the long term (Heckrath et al., 1995), not studying mechanisms in a dynamic and temporal framework may result in loss of valuable information and potential to understand extremes of land management and antecedent conditions. Clearly Type 1 scenarios generate smaller loads and may need less (short term) mitigation requirement than Types 2 and 3 .

Several simple but important rules that can promote progress on understanding of $\mathrm{P}$ transfer have emerged from this work:

- Sample frequency is important and can potentially affect the interpretation of $\mathrm{C}_{\mathrm{p}}-\mathrm{Q}$ relationships and the functional type of an 'event'. Higher sample frequencies could reduce potential uncertainties and so should be a priority.

- In Type 1 conditions, studying soil P does not lead to an understanding of short term P transfer dynamics. Thus, in the short term, static agronomic measures such as Olsen P do not explain the P load and the associated mechanisms.

- Phosphorus form affects $\mathrm{C}_{\mathrm{p}}-\mathrm{Q}$ relationships. In the same catchment in the same event, soluble RP exemplified Type 1 whereas TP (that included particles and colloids) exemplified Type 2.

- A large P source affects $C_{p}-Q$ relationships. A Type 3 response was noted where a slurry source leaked directly to the stream.

- Scale affects $\mathrm{C}_{\mathrm{p}}-\mathrm{Q}$ relationships. Type 1 responses seem to be more common in small scale studies, e.g. in monolith lysimeters, presumably because, at this scale, monoliths are relatively well homogenised. However, it is important to acknowledge that had by-pass flow occurred, a different type of response may have been observed. Nonetheless, this casts doubts on the validity of extrapolating from lysimeters to catchments.

\section{Future challenges}

This simple framework provides a basis for development of a more complex and quantitative classification of $\mathrm{C}_{\mathrm{p}}-\mathrm{Q}$ relationships. The practical benefit of this approach is that it could contribute to a dynamic modelling framework for helping understand $\mathrm{P}$ transfer and delivery from slope to stream and an attemptis now being made to do this. Here, examples from various new data sources have been selected but future improvements could be made from development of a quantitative means to classify 'Type' that takes into account any non-linearity that can exist between $\mathrm{C}_{\mathrm{p}}$ and $\mathrm{Q}$. This is because the main limitation in the classification is that it is qualitative and that subjective judgment is required in interpretation of $\mathrm{C}_{\mathrm{p}}-\mathrm{Q}$ relationships. Another priority for consideration is that, as different processes can lead to the same $\mathrm{C}_{\mathrm{p}}-\mathrm{Q}$ response, they are, in practice, difficult to separate (there are at least three mechanistic explanations for a Type 2 response): this is the problem of geomorphological equifinality as identified previously by Beven (1996). Therefore, there is also a need to develop a system to separate different types of responses, with a subcategorisation to explore finer structure of within-storm hysteresis, to determine whether $\mathrm{C}_{\mathrm{p}}$ peaks occurred before or after the Q peak for Type 2 conditions. This could build on the precedents established in the sediment literature that have earmarked the importance of different conditions for transport versus supply-limited events (e.g. Williams, 1989; Wood, 1977).

This paper has identified the importance of temporal approaches to $\mathrm{P}$ transfer, to help guide future understanding of mechanisms that determine loads (load $=\mathrm{C}_{\mathrm{p}}$.Q). Since $\mathrm{P}$ loads are the basis for export coefficients that are, in turn, used to 'calibrate' spatial/static models (Heathwaite et al., 2003; Johnes and Butterfield, 2002; Lemunyon and Gilbert, 1993) that inform policy decisions, $\mathrm{C}_{\mathrm{p}}-\mathrm{Q}$ dynamics are of fundamental importance. It is intended that this paper serves as a stimulant and commentary on current approaches to the $\mathrm{P}$ transfer issue and highlights the need for future studies to adopt dynamic approaches. Future challenges are to develop quantitative model frameworks that help pinpoint when, where and why these different situations occur.

In a wider context, the classification scheme is dependent on the resolution, duration and overall quality of the input data. As contemporary publications have shown (Kirchner et al., 2000; Kirchner et al., 2001; Kirchner et al., 2004), fine resolution monitoring may reveal additional patterns of complexity. Events therefore may not be linked only or directly to flow and intermittent farm managements, but due to a wide distribution of water and $\mathrm{P}$ through residence times. This fractal response has been shown to occur in similar ways across a large variety of scales. Therefore, the only true understandings in $\mathrm{P}$ hydrochemistry will come about by more high resolution dynamic observations across scales. 


\section{Acknowledgements}

Analytical support of Andrew Bristow, statistical advice from Dan Dhanoa and comments and help of Dr A. C. Edwards, Prof. R. J. Wilkins and Prof C. Neal are gratefully acknowledged. The work was funded by the UK Department for Environment, Food and Rural Affairs (project PEO102), The Biotechnology and Biological Sciences Research Council (UK) (project 89-MAFS12247), The Natural Environment Research Council (UK), the Government of the State of Victoria (Australia) and the Dairy Research and Development Corporation (Australia). The comments of the referees were helpful in improving the manuscript.

\section{References}

Belford, R.K., 1979. Collection and evaluation of large soil monoliths for soil and crop studies. J. Soil Sci., 30, 363-373.

Beven, K.J., 1996. Equifinality and Uncertainty in Geomorphological Modelling. In: The Scientific Nature of Geomorphology, B.L. Rhoads and C.E. Thorn (Eds.), Wiley, Chichester, UK. 289-313.

Cooke, J., 1988. Sources and sinks of nutrients in a New Zealand hill pasture catchment (ii) phosphorus. Hydrol. Process., 2, 123-133.

Eisenreich, S.J., Bannerman, R.T. and Armstrong, D.E., 1975. A simplified phosphorus analytical technique. Environ. Lett., 9, $45-53$.

Genstat 5 Committee, 1993. Genstat 5 Release 3, Clarendon Press. Haygarth, P.M. and Jarvis, S.C., 1997. Soil derived phosphorus in surface runoff from grazed grassland lysimeters. Water Res., 31, 140-148.

Haygarth, P.M. and Sharpley, A.N., 2000. Terminology for phosphorus transfer. J. Environ. Qual., 29, 10-15.

Haygarth, P.M., Ashby, C.D. and Jarvis, S.C., 1995. Short-term changes in the molybdate reactive phosphorus of stored soil waters. J. Environ. Qual., 24, 1133-1140.

Haygarth, P.M., Heathwaite, A.L., Jarvis, S.C. and Harrod, T.R., 2000a. Hydrological factors for phosphorus transfer from agricultural soils. Adv. Agron., 69, 153-178.

Haygarth, P.M., Hepworth, L. and Jarvis, S.C., 1998a. Forms of phosphorus transfer in hydrological pathways from soil under grazed grassland. Eur. J. Soil Sci., 49, 65-72.

Haygarth, P.M. and Jarvis, S.C., 1999. Transfer of phosphorus from agricultural soils. Adv. Agron., 66, 195-249.

Haygarth, P.M., Jarvis, S.C., Chapman, P. and Smith, R.V., 1998b. Phosphorus budgets for two contrasting grassland farming systems in the UK. Soil Use Manage., 14, 160-167.

Haygarth, P.M., Turner, B.L., Fraser, A.I., Jarvis, S.C., Harrod, T.R., Nash, D.M. and Halliwell, D.J., 2000b. Prioritising mitigation of soil phosphorus transfer in relation to water flows. In: Grassland Farming: Balancing Environmental and Economic Demands, K. Soegaard et al. (Eds.), Vol. 5. European Grassland Federation, Holstebro, Denmark.

Haygarth, P.M., Warwick, M.S. and House, W.A., 1997. Size distribution of colloidal molybdate reactive phosphorus in river waters and soil solution. Water Res., 31, 439-442.

Heathwaite, A.L., Fraser, A.I., Johnes, P.J., Hutchins, M., Lord, E., and Butterfield, D., 2003. The phosphorus indicators tool: a simple model of diffuse $\mathrm{P}$ loss from agricultural land to water. Soil Use Manage., 19, 1-12.

Heckrath, G., Brookes, P.C., Poulton, P.R., and Goulding, K.W.T., 1995. Phosphorus leaching from soils containing different phosphorus concentrations in the Broadbalk Experiment. $J$. Environ. Qual., 24, 904-910.

Hergert, G.W., Bourdin, D.R., Klausner, S.D., and Zwerman, P.J., 1981a. Phosphorus concentration-water flow interactions in tile effluent from manured land. J. Environ. Qual., 10, 338-344.

Hergert, G.W., Klausner, S.D., Bouldin, D.R., and Zwerman, P.J., $1981 \mathrm{~b}$. Effects of dairy manure on phosphorus concentrations and losses in tile effluent. J. Environ. Qual., 10, 345-349.

Johnes, P.J. and Butterfield, D., 2002. Landscape, regional and global estimates of nitrogen flux to the sea: Errors and uncertainties. Biogeochemistry, 57/58, 429-476.

Kirchner, J.W., Feng, X. and Neal, C., 2000. Fractal stream chemistry and its implications for contaminant transport in catchments. Nature, 403, 524-527.

Kirchner, J.W., Feng, X. and Neal, C., 2001. Catchment-scale advection and dispersion as a mechanism for fractal scaling in stream tracer concentrations. J. Hydrol., 254, 82-101.

Kirchner, J.W., Feng, X., Neal, C., and Robson, A.J., 2004. The fine structure of water quality dynamics: the (high frequency) wave of the future. Hydrol. Process., In press.

Leaney, F., Smettem, K. and Chittleborough, D., 1993. Estimating the contribution of preferential flow to subsurface runoff from a hillslope using deuterium and chloride. J. Hydrol., 147, 83-109.

Lemunyon, J.L. and Gilbert, R.G., 1993. The concept and need for a phosphorus assessment tool. J. Production Agr., 6, 483-486.

MAFF, 1994. Fertilizer Recommendations for Agricultural and Horticultural Crops. H. M. Stationary Office, London, UK.

McDonnell, J., Stewart, M. and Owens, I., 1991. Effect of catchment scale subsurface mixing on stream isotopic response. Water Resour. Res., 27, 3065-3073.

Murphy, J. and Riley, J.P., 1962. A modified single solution method for the determination of phosphate in natural waters. Anal. Chim. Acta., 27, 31-36.

Nash, D., Halliwell, D. and Hannah, M., 2001. The structure of phosphorus exports and the role of critical incidents. In: Connecting Phosphorus Transfer from Agriculture to Impacts in Surface Waters, P. M. Haygarth et al. (Eds.). Institute of Grassland and Environmental Research, Plymouth. UK. 16pp.

Pionke, H.B., Gburek, W.J., and Folmar, G.J., 1993. Quantifying stormflow components in a Pennsylvania watershed when ${ }^{18} \mathrm{O}$ input and storm conditions vary. J. Hydrol., 148, 169-187.

Pionke, H.B., Gburek, W.J., Sharpley, A.N., and Schnabel, R.R., 1996. Flow and nutrient export patterns for an agricultural hillland watershed. Water Resour. Res., 32, 1795-1804.

Preedy, N., McTiernan, K.B., Matthews, R., Heathwaite, L. and Haygarth, P.M., 2001. Rapid incidental phosphorus transfers from grassland. J. Environ. Qual., 30, 2105-2112.

Rowland, A.P. and Haygarth, P.M., 1997. Determination of total dissolved phosphorus in soil solutions. J. Environ. Qual., 26, 410-415.

Sinaj, S., Stamm, C., Toor, G.S., Condron, L.M., Hendry, T., Di, H. and Cameron, K., 2002. Phosphorus availability and loss from irrigated grassland soils. J. Environ. Qual., 31, 319-330. Stamm, C., Fluhler, H., Gachter, R., Leuenberger, J. and Wunderli, H., 1998. Preferential transport of phosphorus in drained grassland soils. J. Environ. Qual., 27, 515-522.

Turner, B.L., and Haygarth, P.M., 2000. Phosphorus forms and concentrations in leachate under four grassland soil types. Soil Sci. Soc. Amer. J., 64, 1090-1097.

Turner, B.L., and Haygarth, P.M., 2001. Phosphorus solubilization in rewetted soils. Nature, 411, 258.

Williams, G.P., 1989. Sediment concentration versus water discharge during single hydrological events in rivers. J. Hydrol., 111, 89-106.

Wood, P.A., 1977. Controls in variation in suspended sediment concentration in the River Rother, West Sussex, England. Sedimentology, 24, 437-445. 